Article

\title{
Customer's Choice of Purchasing Channel: Do Channel Characteristic, Brand, and Loyalty Matter When Shopping in Hybrid Retailers?
}

\author{
Radka Bauerová *(D) and Veronika Braciníková (iD
}

Citation: Bauerová, R.; Braciníková, V. Customer's Choice of Purchasing Channel: Do Channel Characteristic, Brand, and Loyalty Matter When Shopping in Hybrid Retailers? Sustainability 2021, 13, 2453. https:// doi.org/10.3390/su13052453

Academic Editors: Marc A. Rosen and Jana Majerova

Received: 6 January 2021

Accepted: 21 February 2021

Published: 24 February 2021

Publisher's Note: MDPI stays neutral with regard to jurisdictional claims in published maps and institutional affiliations.

Copyright: (c) 2021 by the authors. Licensee MDPI, Basel, Switzerland. This article is an open access article distributed under the terms and conditions of the Creative Commons Attribution (CC BY) license (https:// creativecommons.org/licenses/by/ $4.0 /)$.
Department of Business Economics and Management, School of Business Administration in Karviná, Silesian University in Opava, Univerzitní Náměstí 1934/3, 73340 Karviná, Czech Republic; bracinikova@opf.slu.cz

* Correspondence: bauerova@opf.slu.cz; Tel.: +420-775-432-486

Abstract: Despite the increasing interest of researchers in the factors that lead customers to buy online, attention has not yet been paid to the factors in hybrid companies, where it is possible to choose both online and offline purchasing channels. Therefore, this paper is focused on investigating the importance of factors that affect customers in both environments. Data were obtained from 1021 respondents using an online panel from the IPSOS research company in Czechia in 2019. Two content analyses were used to obtain results. Attention was also focused on the perception of brand/loyalty in shifting retailers to the online environment or offline environment. The aim of the paper is to find out what factors and how they influence customers when deciding of purchasing channel. The results show the choice of channel is influenced by factors given by channel benefits, the product, brand perception, loyalty, and customer characteristics. Within hybrid retailers, the most preferred purchasing channel is still the offline channel. However, the results also show a significant impact of brand perception and loyalty in the transition of hybrid retailers to a purely online or offline environment, which significantly opens up opportunities for retailing management within sustainable brand management.

Keywords: purchase channel; online shopping; consumer behavior; customers' choice; omnichannel; sustainability; brand; loyalty

\section{Introduction}

One of the essential features of the consumer market is extremely high dynamism [1] which causes and increases market unpredictability. This kind of functioning is influenced by facts that have been relatively well known for many years, including globalization [2], the development of technologies including IT [3], and sudden events, such as the coronavirus pandemic beginning in early 2020 [4]. All these factors change the consumers' preferences of selecting purchasing channels, which the retailers need to react to. For better meeting these preferences, they must be investigated.

Traditional brick-and-mortar retailers have added online channels to maintain their competitive position and relevance for their customers [5]. Because of the rapid development of e-commerce and new digital channels, still, more and more channels are being used by retailers to accomplish transactions between them and consumers, involving websites, physical stores, Internet kiosks, call centers, and mobile apps [6]. The retailer should succeed in this area by integrating online and offline channels because the shopping experience is thus enhanced. The addition of the online channel to the existing store helps to build the loyalty of the consumers towards the offline channel as well as the online one. Customers are likely to develop positive attitudes towards the retailer and are unlikely to be willing to shop elsewhere [7]. 
All of these channels should provide the support of the same goal-retaining the consumers by making them satisfied because satisfaction leads to loyalty [8]. Loyalty is a crucial relational outcome in business-to-consumer relationships. It is determined by the strength of the relationship between the relative attitude of individuals and repeat patronage, which reflects behavioral and attitudinal components of the construct [9]. When consumers are loyal to a retailer, they revisit the retailer, repurchase products, and recommend the product/retailer to relatives or friends [10]. Thus, can the customer be influenced by felt loyalty when choosing the online channel for purchasing? Grocery customers tended to be loyal to the online outlet of their favorite offline channel initially, but, after they gained more experience buying groceries online, they shopped among all online sellers. The implication is that online outlets need to be competitive with the online outlets of other chains [11]. What about the situation across the other product categories? Does the brand of retailer increase consumer's trust in the online purchase channel? These points are part of the research of this study because nowadays many retailers must enhance their selling activity to the online environment and outputs of our research could help the hybrid retailers to improve their knowledge about customers' preferences and react to them more appropriately. That is why it is important to determine whether customers are influenced by factors such as loyalty, product, and brand in a complex way and how these factors influence them to increase knowledge of customer behavior in hybrid companies' field and to present how this knowledge can be used by marketing managers for customer acquisition and retention. Therefore, the research question of the study is formulated as follows: How customers are influenced by purchasing channel, product, brand, and loyalty when deciding on a hybrid company's purchasing channel, and is the decision-making influenced by customer characteristics?

\section{Literature Review}

For consumers, the choice of a purchasing channel depends mainly on economic factors relevant to a consumer's channel choice, such as search cost, delivery time, evaluation cost, and price [12]. Price seems to be one of the most important criteria to evaluate a purchase, but it can be less considered if the factors such as personalization, stock availability, and convenience are important for the customer [13]. Whereby convenience means that the customer seeks to purchase a product with a minimum investment of time, physical effort, and mental effort [14].

Most consumers are cross-shoppers and tend to shop on a channel for products suitable for that channel [15]. Consumers perceive that the online channel in comparison to offline channel offers greater product selection [16]. The consumers can get a large amount of information about product attributes and its availability. They can compare prices and overall value proposition very quickly or get online recommendations from different sources [17-19].

Shopping online allows consumers to search product information from different vendors from one computer screen, therefore search costs, when shopping online, will increase more slowly with the number of products searched than shopping in-store. Hence, in the traditional channel, the marginal search cost increases with the number of products, and, in the electronic channel, it is constant [15]. It follows that one of the reasons for preferring online purchases is the variety of offers that cannot be found in physical stores [20]. Afterwards, if the product can be delivered quickly at a relatively low cost, the online channel is preferred, whereas if the delivery cost is high and customers are impatient, the traditional brick-and-mortar store is chosen [21]. The increasing use of customer supportive technologies and applications within the physical retail store has enhanced shopping experience and store atmosphere [22]. Feeling the right personal experience at a certain retail store can be a very important evaluative factor and lead the customer to repeat purchase to feel the experience again [23]. 


\subsection{Brand Perceptions}

The offline brand image of a multichannel retailer that the consumers have adopted through their past experiences with the retailer may influence the consumer's online loyalty toward the retailer directly or indirectly through its impact on online brand image. However, these findings do not allege that multichannel retailers should ignore their online performance and focus just on fostering offline brand images. Given the major influence of the online performance manipulation on online brand image, the actual performance of a website influences consumers' online attribute evaluation, suggesting the importance of the smooth integration and consistent image management among multichannel retailer's online and offline operations [24].

Moreover, consumers are more likely to trust a brand that they can experience offline [25], which gives multichannel retailers operating on the market a potential advantage over pure online retailers. Because multichannel retailer can build through the offline channel the necessary customer trust to buy online. From the study focused on the investigation of the link between brand trust and behavioral intentions for a multichannel retailer, indirect links between confidence in the online store and online search intention are obvious [26]. Similarly, consumers' trust in an apparel retail brand influences intention to shop at the retailer's website. Thus, brand trust can be considered as a strong driver of loyal behaviors in the multichannel context $[27,28]$, which represents the basis of the first hypothesis:

Hypothesis 1 (H1). Brands of retailers operating in a multichannel base increase their trustworthiness among the consumers.

\subsection{Customer Loyalty}

Retailers or brands could achieve more success by focusing on findings of how they can satisfy specific segments of shoppers [29]. There are three main groups of consumers appearing on the market called generations-Generation Y, Generation X, and Baby Boomers. Generation Y, also known as the Millennials, are considered one of the most important segments for online retailers [30] because of their massive purchasing power. In addition, their unmatched technical skills are crucial to the success of retailers operating in the online environment [31].

Exploration of generational differences in digital behavior is crucial when developing marketing strategies targeted to consumers who use a particular retail channel or channels. [32]

For instance, Generation X adopts new technology at a slower rate than Generation $\mathrm{Y}$ but faster than Baby Boomers [33]. Older consumers prefer shopping in traditional brick-and-mortar stores, while younger ones prefer shopping online [32].

Additionally, the association of integration of online and offline channels with consumers' shopping behavior, including product search, intention to buy, and willingness-topay, differed by product category [34]. Moreover, online shoppers have favorable intentions towards buying the same brand in a brick-and-mortar store [32,35].

Thus, as long as consumers are satisfied with their prior experience with the retailer, they are likely to repeat their purchases according to the reduced cognitive effort and efficiency of purchase [36]. However, because of the lower switching costs of consumers when they shop online, they can easily choose another retailer when they feel dissatisfied with their purchase $[37,38]$. In other words, satisfying customers' needs plays a more fundamental role in retaining their future patronage in online purchases. The effect of customer satisfaction on customer loyalty is stronger (more positive) for online than offline purchases [39]. From this point of view, we can state the hypothesis as follows:

Hypothesis 2 (H2). The intensity of shopping online in the case of consumers of Generation X and Generation $Y$ causes them to tend to switch brands when buying products much more often than Baby Boomers. 


\subsection{Product Categories}

Some studies $[40,41]$ have found that product category affects multichannel shopper behavior. It means that product category influences shopping intentions in the terms of choosing shopping channel. Goods for which investigation of their characteristics before purchasing is economically feasible are referred to search goods, such as electronics. Goods such as apparel, for which this kind of research is not economically feasible, are termed experience goods. Whereby it is considered that the offline channel could be more preferred for purchasing experience goods compared to purchasing search goods [28]. Earlier studies [42] have shown that the products which consumers need to touch or try on represent products which require a presence or purchasing within an offline channel [43].

Another study [44] also assumed that the ability to personally encounter a product before purchasing is a fundamental factor of the preference for an offline shopping channel for products such as clothing. Nevertheless, apparel goods have found mass acceptance in the retail of the online environment. Moreover, no branch of the industry has been more affected by the Internet than retail sales $[43,45]$. Thus, these findings have led us to the formulation of the third hypothesis:

Hypothesis 3 (H3). The preferred purchasing channel varies depending on the category of purchased products.

\subsection{Sociodemographic Characteristics}

Consumer's channel choice could also be affected by their sociodemographic characteristics (age, gender, and number of children), user experience (prior channel experience, number of prior purchases, and web purchase frequency), communication efforts (direct and interaction effects of e-mail or catalogue), time trend (seasonality and vacation period), distance to the nearest retail shop, expenses for direct marketing communication, and squared marketing communication [46,47]. Moreover, sociodemographic factors such as age, income, gender, educational level and nature of job have a positive impact on consumer impulse buying behavior [48,49].

Sociodemographic characteristics become important when consumers face with new things. When all consumers become more experienced in online shopping, their behavior becomes much more similar and sociodemographic factors do not differ anymore. Consequently, analyzing behaviors of online consumers gave wonderful results and played an essential part of marketing science [49,50].

Besides, there is evidence [51] about gender influencing the importance of antecedents of channel choice for electronics, but age and occupation were not relevant. Gender also affects the adoption of multichannel, male consumers being more likely to adopt a new channel, which cannot be from the study assumed about income [52]. Multichannel shoppers were younger than the offline ones and just online customers were younger than multichannel shoppers [40]. In addition, intentions to purchase online relate positively to customer age and they are higher for apparel in comparison to electronics customers [28]. Thus, there is some conclusive evidence on the effect of some sociodemographic variables on multichannel behavior, which represents the basis for the fourth hypothesis:

Hypothesis 4 (H4). Within the offline environment, unlike the online environment, the factors influencing the channel selection are not influenced by the characteristics of the respondents (generation, education, and place of residence).

The literature has detected many factors which have an impact on purchasing channel choice of consumers, but are these factors relevant to our environment? What other decisive factors resulting from the characteristics of both purchasing channels influence their selection? The authors sought answers to these questions in this study.

As the literature has detected, multichannel shoppers have been investigated by researchers from many points of view. However, the systematic research on the complexity 
of the factors such as brand perception, loyalty, product, and sociodemographic factors influencing the consumers' decision-making process of selecting channels is missing. Thus, the focus of this study covers this research gap in our environment.

\section{Materials and Methods}

The first step in the research was to obtain primary data based on the findings of the literature review. Due to the investigated theme, CAWI was identified as the most suitable method. The data collection was therefore carried out through an online questionnaire. The questionnaire also included open-ended questions to ensure the respondents' limitless answers in the section where identification of factors given by purchasing channel was an investigation. For an overview, Supplementary Materials (Survey S1) is attached to the paper, which contains a transcript of all questions from the online questionnaire and their type. The second step was data cleaning to ensure the relevance of the respondents responses. At this stage, a logical check was performed. All data were examined for missing values and standard deviation. In total, 29 questionnaires with careless answers were removed based on this procedure. The remaining data were subsequently tested and analyzed by using the IBM SPSS software (version 21.0, International Business Machines Corporation, Armonk, NY, USA). First, the influence of product itself, brand, loyalty, and demographic variables on purchasing channel selection decisions was examined. Subsequently, individual subjective factors related to purchasing channel benefits that may influence customer decision-making were examined. The last step was to create a scheme of the most important factors influencing the decision-making process in the case of choosing the purchasing channel type.

\subsection{Sample}

Probability sampling was selected as the type of sample to reduce sample bias. Experience with online product purchasing was chosen as a criterion due to research focused on hybrid organizations. To provide a relevant research sample of respondents from the majority of generations of customers (Generation Y, Generation X, and Baby Boomers), the research agency Ipsos was used to collect primary data. Simple Random Sampling is a method of obtaining information by the research agency, where each member meeting the criteria is randomly selected. Ipsos guarantees the distribution of a representative sample across all regions, genders, age categories, places of residence, and education. Ipsos provides the Instant Research tool that was chosen for data collection. This online panel is audited by the professional association SIMAR and has obtained a certificate of quality of services provided. It is also part of the professional associations ESOMAR, MSPA, SAVA, and joined the UN Global Compact initiative. Using their online data collection tool, responses were obtained from 1050 respondents. By data cleaning process, 1021 relevant respondents were included in the research. Table 1 shows the characteristics of these respondents.

The distribution of the sample is balanced in terms of gender, individual generations, and distribution according to the city size. The distribution of the sample from the point of view of education corresponds to the usual distribution of the acquired education in the examined population. 
Table 1. The structure of the research sample according to chosen demographic factors.

\begin{tabular}{cccc}
\hline \multirow{2}{*}{ Demographic Features } & $\begin{array}{c}\text { Number of Respondents } \\
(\mathbf{N}=\mathbf{1 0 2 1})\end{array}$ & Percentage \\
\hline \multirow{2}{*}{ Gender } & Female & 486 & 47.6 \\
& Male & 535 & 52.4 \\
\hline \multirow{3}{*}{ Generation } & Baby Boomers & 317 & 31.0 \\
& Generation X & 323 & 31.6 \\
& Generation Y & 381 & 37.3 \\
\hline \multirow{4}{*}{ Education } & Basic & 89 & 8.7 \\
& Secondary without A-level & 346 & 33.9 \\
& Secondary with A-level & 409 & 40.1 \\
& Tertiary & 177 & 17.3 \\
\hline \multirow{2}{*}{ Distribution by } & Up to 1000 inhabitants & 160 & 15.7 \\
city size & $1001-5000$ inhabitants & 213 & 20.9 \\
& $5001-20,000$ inhabitants & 175 & 17.1 \\
& 20,001-100,000 inhabitants & 217 & 21.3 \\
\hline
\end{tabular}

\subsection{Data Analysis}

The one-way analysis of variance (ANOVA) was used to determine whether there are any statistically significant differences between the means of purchased channel type preferences. The Kruskal-Wallis $\mathrm{H}$ test was used to analyze the influence of brand, loyalty, and demographic factors on the choice of the type of purchasing channel (offline/online). This test was selected based on an examination of the nature of the obtained relevant data. The first prerequisite for using this test is to verify normality. Since the null hypothesis of normality was rejected, the data meet the mentioned assumption for the use of the Kruskal-Wallis $\mathrm{H}$ test (the data do not have a normal distribution). The second premise is independence. The primary data also meet this assumption.

In the second phase of the research, factors given by purchasing channel from the point of view of customers' opinion were analyzed. Content analysis was chosen for this step as a relevant method given the two Open-Ended questions. In these questions, respondents were asked to describe why they shop online/offline. There was a necessity to conduct two content analysis to obtain the requested results. First, a content analysis of the decisive factors within the e-shop was performed. The classification of the obtained answers employing content analysis was performed by conceptual analysis. The main goal was to explore implicit expressions. The text was then encoded into content categories (named as factors). The level of analysis was at the level of the sentence. An interactive set of categories was developed, which allowed flexibility in adding categories through the coding process. This procedure has enabled the introduction and analysis of new and important findings that may have significant implications for the research question. Attention was paid to the existence of the concept in the text, therefore the concept was calculated only once within one text answer. The coding rule was that all logical word variations fall into one code. According to the rules, all texts were subsequently encoded into the appropriate codes. The coding was done manually, as no software would be able to encode the text in the Czech language. However, this is also an advantage, because, if the encoding is done manually, the researcher can recognize the error much more easily. In the last phase, the results were analyzed and interpreted. This procedure was applied based on knowledge devoted to methods of primary data collection and the procedure of their analysis in marketing research [53]. Subsequently, the frequency analysis was used to find the most important factors influencing customers when choosing an online purchasing channel. In the case of factors within the brick-and-mortar store, the same procedure was performed.

The results of the analyses were subsequently used to create a scheme of the most important factors influencing the decision-making process in the case of choosing the 
type of purchasing channel. The comparison also examined whether the reported factors given by purchasing channel, brand perception, and loyalty are significantly influenced by the characteristics of the respondents, or whether they are factors that are decisive for customers in the choice of purchasing channel regardless of their characteristics (given by demographic factors).

\section{Results}

The first partial research question is focused on finding out whether customers also compare online offers before buying in a traditional brick-and-mortar store. Figure 1 shows the results of the frequency analysis. It was found that $81 \%$ of respondents compare online offers before buying in a brick-and-mortar store and $47 \%$ of respondents eventually decide to choose an online purchasing channel. It can therefore be confirmed that the product itself influences the decision to choose the purchasing channel.

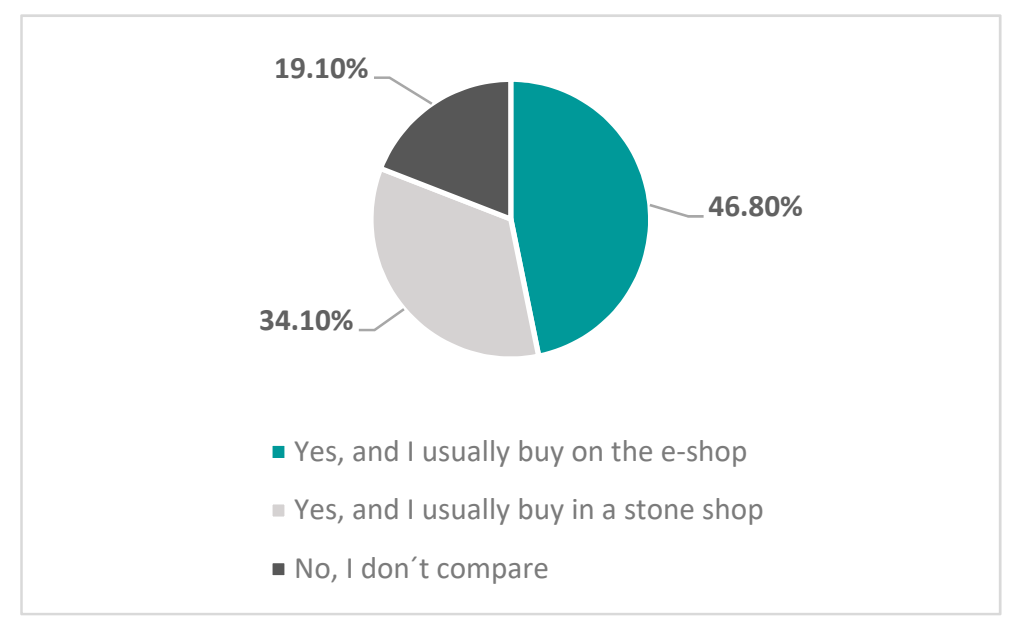

Figure 1. Comparing offers within purchasing channels.

While the previous finding shows that an online purchasing channel is a clear choice for every second customer when comparing the offer of online and offline retailers, it does not show the situation of hybrid retailers. The question is: If retailer operate in both online and offline environments, what is the preferred channel? To find the answer, it was necessary to compare several retailers from the main categories of online products, which also operate in an offline environment (Table 2). These hybrid retailers offer the same range of services (in online and offline environments), and therefore this analysis shows more precisely which type of purchasing channel customers prefer in brands trading in both markets.

The results of the analysis (Table 2) show that, when customers have a choice of two types of purchasing channels at one retailer, most always choose a traditional offline channel. Based on the analysis of variance results (Table 3), it is clear that the online category of products also plays a role in the selection of the shopping channel. Therefore, the third hypothesis was supported. The preferred purchasing channel varies depending on the category of purchased products. Based on previous results it is clear that, in the case of electronics, there is a much higher proportion of customers who prefer online purchasing channel than in the case of other examined online categories.

Besides, customers' choice of the preferred channel may be influenced by other factors. Therefore, attention was further focused on demographic factors, brand perception, and customer loyalty. In the following sections, these factors and their role in selecting the purchasing channel are analyzed. 
Table 2. Preferred channel type of hybrid retailers by customers.

\begin{tabular}{cccc}
\hline \multirow{2}{*}{ Hybrid Retailer } & Online Category & \multicolumn{2}{c}{ Preferred Channel Type } \\
\cline { 3 - 4 } & & Online & Offline \\
\hline Tesco & Grocery & $6.37 \%$ & $93.63 \%$ \\
Hervis & Sport clothes & $20.37 \%$ & $79.63 \%$ \\
Sportisimo & Sport clothes & $24.98 \%$ & $75.02 \%$ \\
Okay elektro & Electronics & $36.83 \%$ & $63.17 \%$ \\
Electro world & Electronics & $39.86 \%$ & $60.14 \%$ \\
Dr. Max & Pharmacy & $19.59 \%$ & $80.41 \%$ \\
Deichmann & Footwear and accessories & $11.07 \%$ & $88.93 \%$ \\
CCC & Footwear and accessories & $11.46 \%$ & $88.54 \%$ \\
IKEA & Furniture and appliances & $16.85 \%$ & $83.15 \%$ \\
Jysk & Furniture and appliances & $14.69 \%$ & $85.31 \%$ \\
\hline
\end{tabular}

Table 3. The results of ANOVA tests.

\begin{tabular}{ccccccc}
\hline \multirow{2}{*}{$\begin{array}{c}\text { Preferred } \\
\text { Channel } \\
\text { Type }\end{array}$} & & \multicolumn{5}{c}{ Online Category } \\
\cline { 3 - 6 } & & $\begin{array}{c}\text { Sum of } \\
\text { Squares }\end{array}$ & df & $\begin{array}{c}\text { Mean } \\
\text { Square }\end{array}$ & F-Statistic & Sig. \\
\hline \multirow{3}{*}{ Online } & Between Groups & 61.18 & 1 & 61.18 & 39.039 & 0.000 \\
& Within Groups & 28.21 & 18 & 1.567 & & \\
\hline \multirow{3}{*}{ Offline } & Total & 89.39 & 19 & & 26.871 & 0.000 \\
& Between Groups & 42.11 & 1 & 42.11 & & \\
\hline & Within Groups & 28.21 & 18 & 1.567 & & \\
\hline
\end{tabular}

\subsection{Demographic Factors}

Despite refraining from examining the impact of demographic factors on customers, it was found that, in the case of hybrid companies, these factors play a role in deciding the purchasing channel. Thus, the choice of purchasing channel for hybrid retailers is also influenced in some way by the generation, size of the place of residence, and education. The customer's affiliation to a certain generation affects in the case of the purchase of sportswear and electronics (as Sportissimo-sig. $=0.011$, Okay electro-sig. $=0.012$, Electro world sig. $=0.023$; all significances are lower than the level of 0.05 ). The size of the place of residence has an effect in the case of grocery shopping, pharmacy, and footwear (as Tescosig. $=0.000$, Dr.Max-sig. $=0.011$, CCC-sig. $=0.000$; all significances are lower than the level of 0.05). Education has an impact on buying sportswear, electronics, pharmacy, shoes, and furniture (as Hervis-sig. $=0.014$, Okay elektro-sig. $=0.000$, Electro world-sig. $=0.000$, Dr. Max-sig. $=0.000$, CCC-sig. $=0.002$, IKEA-sig. $=0.013$; all significances are lower than the level of 0.05).

\subsection{Brand Perception}

Based on the evaluation of the issue of brand perception, it was found that brand perception influences the choice of shopping channel. Evaluation of the answers using frequency analysis showed that $82 \%$ of customers have more confidence in buying goods online compared to the remaining $18 \%$. It was then tested whether brand perception and its impact on trust are influenced by the generation to which respondents belong, educational attainment, and size of place of residence. The results of the Kruskal-Wallis H Test (Table 4) revealed that brand perception and its impact on trust is influenced by the generation to which the respondent belongs (as sig. $=0.000<0.05$ ). For other demographic factors, the effect on the perception of trust in the brand was not proven (education-sig. $=0.674>0.05$, size of place of residence-sig. $=0.125>0.05$ ) . 
Table 4. The results of the Kruskal-Wallis H tests (brand perception).

\begin{tabular}{cccc}
\hline \multirow{2}{*}{$\begin{array}{c}\text { Kruskal-Wallis } \\
\text { H Test }\end{array}$} & Generation & Education & Size of a Place of Residence \\
\cline { 2 - 4 } & 22.198 & 1.534 & 7.214 \\
Chi-Square & 2 & 3 & 4 \\
Df & 0.000 & 0.674 & 0.125 \\
Sig. & &
\end{tabular}

A more detailed look at this finding using frequency analysis is given in Table 5.

Table 5. The influence of a well-known retailer brand on trust in the online environment.

\begin{tabular}{ccccc}
\hline $\begin{array}{c}\text { Type of } \\
\text { Generation }\end{array}$ & Definitely Not & Rather Not & Rather Yes & Definitely Yes \\
\hline Generation Y & $1.57 \%$ & $12.60 \%$ & $42.26 \%$ & $43.57 \%$ \\
Generation X & $1.86 \%$ & $13.00 \%$ & $50.77 \%$ & $34.37 \%$ \\
Baby Boomers & $6.62 \%$ & $17.98 \%$ & $52.37 \%$ & $23.03 \%$ \\
\hline
\end{tabular}

Based on the results of the Kruskal-Wallis H test (Table 4), it was found that the generation has an impact on the perception of the trust of the retailer's brand, which in turn leads to greater trust in the online environment. However, if we look in more detail at the results of the frequency analysis (Table 5), it is obvious that the percentage differences between the generations $\mathrm{Y}$ and $\mathrm{X}$ are not so significant and are in the order of a maximum of $9.2 \%$. Both generations state to a greater extent that the brand influences their choice of purchasing channel. Compared to them, the Baby Boomers generation is more restrained in this trust, and the brand does not have as strong an effect as on the other generations studied. Nevertheless, even in this case, $75 \%$ of respondents of this generation (see Table 4-rather yes and definitely yes) stated that the brand influences the choice of purchasing channel, which is still a large proportion. However, based on the results of the analysis, the first hypothesis can be supported. Thus, brands of retailers operating in a multichannel base increase their trustworthiness among the consumers.

\subsection{Customer Loyalty}

Customer loyalty was examined in the hypothetical situation where e-retailers would stop offering an online shopping channel and move fully to an offline environment. Respondents were asked if they would continue to shop with their favorite retailer if it took this step. This question was preceded by questions on whether the respondents buy from selected retailers who, at the time of data collection, operate on the Czech market only in the online environment (these e-retailers were Košík.cz, Rohlík.cz, Notino.cz, Krasa.cz, Alza.cz, and Mall.cz). Overall, the results of frequency analysis show that, if retailers that trade only online went fully offline, $54 \%$ of their customers would remain loyal to them, despite being limited in their choice of shopping channel. However, $46 \%$ of customers do not feel such a level of loyalty, and these customers would stop shopping at these retailers.

Based on the Kruskal-Wallis $\mathrm{H}$ test (Table 6), it was found that customer loyalty varies according to the generation to which customers belong (sig. $=0.029)$ and what kind of education they have received (sig. $=0.002$ ). The effect of size of residence on customer loyalty has not been proven (sig. $=0.568$ ). 
Table 6. The results of the Kruskal-Wallis H test (customer loyalty).

\begin{tabular}{cccc}
\hline \multirow{2}{*}{$\begin{array}{c}\text { Kruskal-Wallis } \\
\text { H Test }\end{array}$} & Generation & Education & Size of a Place of Residence \\
\cline { 2 - 4 } & 7.078 & 14.622 & 2.940 \\
Chi-Square & 2 & 3 & 4 \\
Df & 0.029 & 0.002 & 0.568 \\
Sig. & & & \\
\hline
\end{tabular}

Table shows 7 whether the results of customer degree of loyalty are influenced by demographic factors.

Based on the results of analyses, the second hypothesis was supported. Therefore, the intensity of shopping online in the case of consumers of Generation X and Generation $\mathrm{Y}$ causes them to tend to switch brand when buying products much more often than Baby Boomers. Although education and generation were found to influence perceptions of loyalty (Table 6), the differences between the various variables of these demographic factors are very small, as shown in Table 7.

Table 7. Loyalty to the e-tailer in terms of demographic factors.

\begin{tabular}{ccc}
\hline Type of Demographic Factor & Disloyal to the Brand & Loyal to the Brand \\
\hline Education & & \\
\hline Basic & $50.56 \%$ & $49.44 \%$ \\
\hline Secondary without A-level & $40.46 \%$ & $59.54 \%$ \\
\hline Secondary with A-level & $45.48 \%$ & $54.52 \%$ \\
\hline Tertiary & $57.63 \%$ & $42.37 \%$ \\
\hline Generation & \\
\hline Generation Y & $51.71 \%$ & $48.29 \%$ \\
\hline Generation X & $43.34 \%$ & $56.66 \%$ \\
\hline Baby Boomers & $42.90 \%$ & $57.10 \%$ \\
\hline
\end{tabular}

\subsection{Factors Given by Purchasing Channel}

In the last phase of the research, we focused on the analysis of possible other factors given by purchasing channel supporting the choice of a specific channel type. The first content analysis was focused on the factors that influence the decision to choose an online channel for purchasing the product. Subsequently, the second content analysis was performed in the same way for offline channel decision.

\subsubsection{Factors Leading to the Choice of Online Purchasing Channel}

The 19 most important decisive factors with the greatest influence in deciding on the choice of an online shopping channel were identified by the first content analysis. Of these factors, only eight are shown in Table 8, given that the other factors did not reach the set criterion of $5 \%$ (in the case of the unlimited shopping factor, the criterion is met in a rounded value); the other identified factors are presented in Supplementary Materials (Table S1). These factors were named based on the common features of the variables defining each factor. 
Table 8. Factors leading to online purchasing channel.

\begin{tabular}{|c|c|c|c|}
\hline Factor & Variables Forming the Factor & Percent & Overall Ranking \\
\hline Cost-effective & $\begin{array}{c}\text { Better price comparison of individual } \\
\text { e-shops, better price comparison } \\
\text { through price comparators, } \\
\text { cost-effective, lower price, } \\
\text { price flexibility. }\end{array}$ & 25.7 & 1. \\
\hline Comfort & $\begin{array}{l}\text { Shopping from home, no parking, } \\
\text { comfort, convenience, there is no need } \\
\text { to go anywhere. }\end{array}$ & 15.4 & 2. \\
\hline Better choice & $\begin{array}{l}\text { Possibility of a larger selection of goods } \\
\text { of various sellers and parameters, wider } \\
\text { assortment, possibility of better } \\
\text { comparison of similar products, an } \\
\text { overview of e-shop competition, } \\
\text { compare goods in more e-shops, more } \\
\text { time to look at the goods, the possibility } \\
\text { of choose from many brands, popular } \\
\text { brands, goods that may be insufficient } \\
\text { in traditional stores, all in one place. }\end{array}$ & 8.9 & 3. \\
\hline Speed purchase & $\begin{array}{l}\text { Speed of purchase, faster than looking } \\
\text { for goods in brick-and-mortar shops. }\end{array}$ & 7.8 & 4. \\
\hline WOM & $\begin{array}{l}\text { The opportunity to read reviews, } \\
\text { recommendations of acquaintances, } \\
\text { reviews of other customer, product } \\
\text { reviews by a customer who has already } \\
\text { bought the product, possibility to see } \\
\text { responses to the brand and goods, } \\
\text { reviews on websites, positive reviews. }\end{array}$ & 6.4 & 5. \\
\hline $\begin{array}{l}\text { Purchase delivery } \\
\text { options }\end{array}$ & $\begin{array}{l}\text { Reliable and fast transport, speed of } \\
\text { delivery, choice of place of delivery and } \\
\text { low postage, the possibility of personal } \\
\text { collection, collection points, the } \\
\text { possibility to pick up the goods in the } \\
\text { physical location of online store. }\end{array}$ & 6.0 & 6. \\
\hline Time savings & $\begin{array}{l}\text { Saves time, the possibility to show more } \\
\text { stores in a few minutes, saving time } \\
\text { because of home shopping. }\end{array}$ & 5.7 & 7. \\
\hline $\begin{array}{l}\text { Unlimited } \\
\text { shopping }\end{array}$ & $\begin{array}{l}\text { Possibility to buy at any time and from } \\
\text { anywhere, availability of service, } \\
\text { possibility to buy from the far store, } \\
\text { non-stop purchases, simply buying from } \\
\text { abroad stores. }\end{array}$ & 4.9 & 8. \\
\hline
\end{tabular}

The performed analysis also showed that, within the examined group of respondents, there were 73 neutral answers, 8 answers with negative sentiment, and 12 answers with positive sentiment. Neutral answers and answers with negative and positive sentiment together accounted for $9.1 \%$ of respondents. However, due to their vague nature, these variables were not included in the decisive factors.

Using the Kruskal-Wallis $\mathrm{H}$ test, it was subsequently tested whether the stated decisive factors differ according to the characteristics of the respondents (Table 9). Generation, education, and size of residence were chosen as variables define the characteristics of the respondents. 
Table 9. The results of the Kruskal-Wallis $\mathrm{H}$ test (online purchasing type).

\begin{tabular}{cccc}
\hline \multirow{2}{*}{$\begin{array}{c}\text { Kruskal-Wallis } \\
\text { H Test }\end{array}$} & Generation & Education & Size of a Place of Residence \\
\cline { 2 - 4 } Chi-Square & 2.211 & 2.751 & 3.730 \\
Df & 2 & 3 & 3 \\
Sig. & 0.331 & 0.432 & 0.292 \\
\hline
\end{tabular}

None of the mentioned variables showed a significant effect on the decisive factors in the case of the online shopping channel (generation-sig. $=0.331>0.05$, education-sig. $=0.432>0.05$, size of place of residence-sig. $=0.292>0.05$ ).

\subsubsection{Factors Leading to the Choice of Offline Purchasing Channel}

The second content analysis was focused on the identification of factors that influence the decision process of the consumers about choosing a brick-and-mortar store as the purchasing channel. By this analysis, 18 main factors were detected. Of these factors, only five are shown in Table 10, as the other factors did not reach the set criterion of 5\%; the other identified factors are presented in Supplementary Materials (Table S2). All of the factors are determined by variables that have a similar meaning within each factor and also define the name of these factors.

Table 10. Factors leading to offline purchasing channel.

\begin{tabular}{|c|c|c|c|}
\hline Factor & Variables Forming the Factor & Percent & Overall Ranking \\
\hline $\begin{array}{l}\text { Ability to see and } \\
\text { try out goods }\end{array}$ & $\begin{array}{l}\text { Possibility to view, touch, try out, and } \\
\text { compare the goods, opportunity to } \\
\text { physically inspect the goods and check } \\
\text { the quality, appearance of goods, contact } \\
\text { with goods. }\end{array}$ & 53.5 & 1. \\
\hline Type of product & $\begin{array}{l}\text { The products, which need to be touched } \\
\text { or tried out-groceries, shoes, clothes, } \\
\text { interactive toys, perfumes; more } \\
\text { expensive goods-electronics, the } \\
\text { equipment of the apartment; goods of } \\
\text { daily use-small drugstore goods; items, } \\
\text { where the transport is more expensive } \\
\text { than goods-sundries and } \\
\text { smaller purchases. }\end{array}$ & 9.4 & 2. \\
\hline Speed & $\begin{array}{l}\text { No waiting for delivery, immediate } \\
\text { availability of goods, faster arranging of } \\
\text { claims, quicker change of goods. }\end{array}$ & 5.7 & 3. \\
\hline Price and sale & $\begin{array}{c}\text { Lower prices, price promotions, } \\
\text { discounts, special offers, no } \\
\text { delivery fees. }\end{array}$ & 5.2 & 4. \\
\hline Service & $\begin{array}{l}\text { Customer service, personal approach, } \\
\text { possibility to consult with sellers and } \\
\text { get advice, possibility to ask an expert } \\
\text { for more information. }\end{array}$ & 5.0 & 5. \\
\hline
\end{tabular}

Besides these answers of the respondents that have quite concrete meaning and create the factors, there were also responses with an inexact sense that were not included in the analysis. These responses are formed by 17 answers with positive sentiment, 7 answers with negative sentiment, and 28 answers with a neutral sentiment. The total amount of the respondents' reactions with positive, negative, and neutral sentiment is appearing at the level of $5.1 \%$. 
As in the case of decisive factors regarding choosing an online channel for purchasing, in the case of choosing offline channel, the three characteristics such as the generation of the consumers, educational attainment, and size of residence were chosen. These demographic factors were chosen to test the connections among them and the differentiation of the identified factors by Kruskal-Wallis $\mathrm{H}$ test (Table 11).

Table 11. The results of the Kruskal-Wallis H test (offline purchasing type).

\begin{tabular}{cccc}
\hline \multirow{2}{*}{$\begin{array}{c}\text { Kruskal-Wallis } \\
\text { H Test }\end{array}$} & Generation & Education & Size of a Place of Residence \\
\cline { 2 - 4 } Chi-Square & 1.047 & 0.547 & 3.436 \\
Df & 2 & 3 & 4 \\
Sig. & 0.592 & 0.908 & 0.488 \\
\hline
\end{tabular}

However, the Kruskal-Wallis $\mathrm{H}$ test did not show any significant effect of any demographic factor on decisive factors connected to choosing offline shopping channel (generation-sig $=0.592>0.05$, education-sig. $=0.908>0.05$, size of place of residence-sig. $=0.488>0.05$ ).

Based on the results of the analyses, the fourth hypothesis is rejected. Thus, within the offline and online environment, the factors influencing the channel selection are not influenced by the characteristics of the respondents (generation, education, and place of residence).

\section{Discussion}

The research was based on the assumption that today's customers have a choice between online and offline shopping channels in the decision-making process for most products. Another assumption was that their final decision is jointly influenced by both the factors given by these channels and the factors that can be influenced by the retailers themselves. The research showeds that the choice of purchasing channel is influenced by the product itself, as confirmed by previous studies $[16,19,46]$, but it was also found that, when the presumption of influence of the product offered is reduced (by examining hybrid companies), so other factors influence the choice of shopping channel. In the case where customers have the same product to choose from the same online and offline retailer, it was found that the traditional offline channel is still preferred in all online categories. Here, the fact related to this shopping channel plays a role as well. The most important of these are the ability to see and try out goods, speed, price and sale, service, and type of product. However, the final decision is also influenced by the perception of the brand, which significantly supports confidence in the online purchase of goods. Overall, up to $82 \%$ of customers have more confidence in the online channel, which makes them more likely to choose this channel if it is a well-known retailer brand. Besides, our results confirm the outputs of a previous study [25] that retailers are more trusted by consumers when they operate in multiple channels. Perceived loyalty can also influence the choice of a shopping channel, even for every second customer, and vice versa as these results support the outputs of the study [32] that online shoppers have favorable intentions towards buying the same brand in a brick-and-mortar store. However, these findings have some limitations. Younger consumers tend to switch the brands substantially more quickly than older consumers who are not as online as the younger ones. For customers who eventually chose an online shopping channel, factors based on this environment also influenced them. The biggest influence in this environment was the factor costeffective, comfort, better choice, speed purchase, and WOM. This part of the research confirms the results of previous studies $[20,21]$ but deepens the knowledge of other factors influencing customers when choosing an online shopping channel. Most of the results were influenced by the personal characteristics of the respondents, given by selected demographic factors (generation, education, and size of residence), which leans towards 
previous research [46,47]. Although demographic factors are abandoned in marketing research, the results show that demographic factors still play a role as their influence on the choice of the preferred shopping channel, perception of loyalty and brand. Figure 2 presents a diagram showing the influence of the examined factors on the choice of the shopping channel.

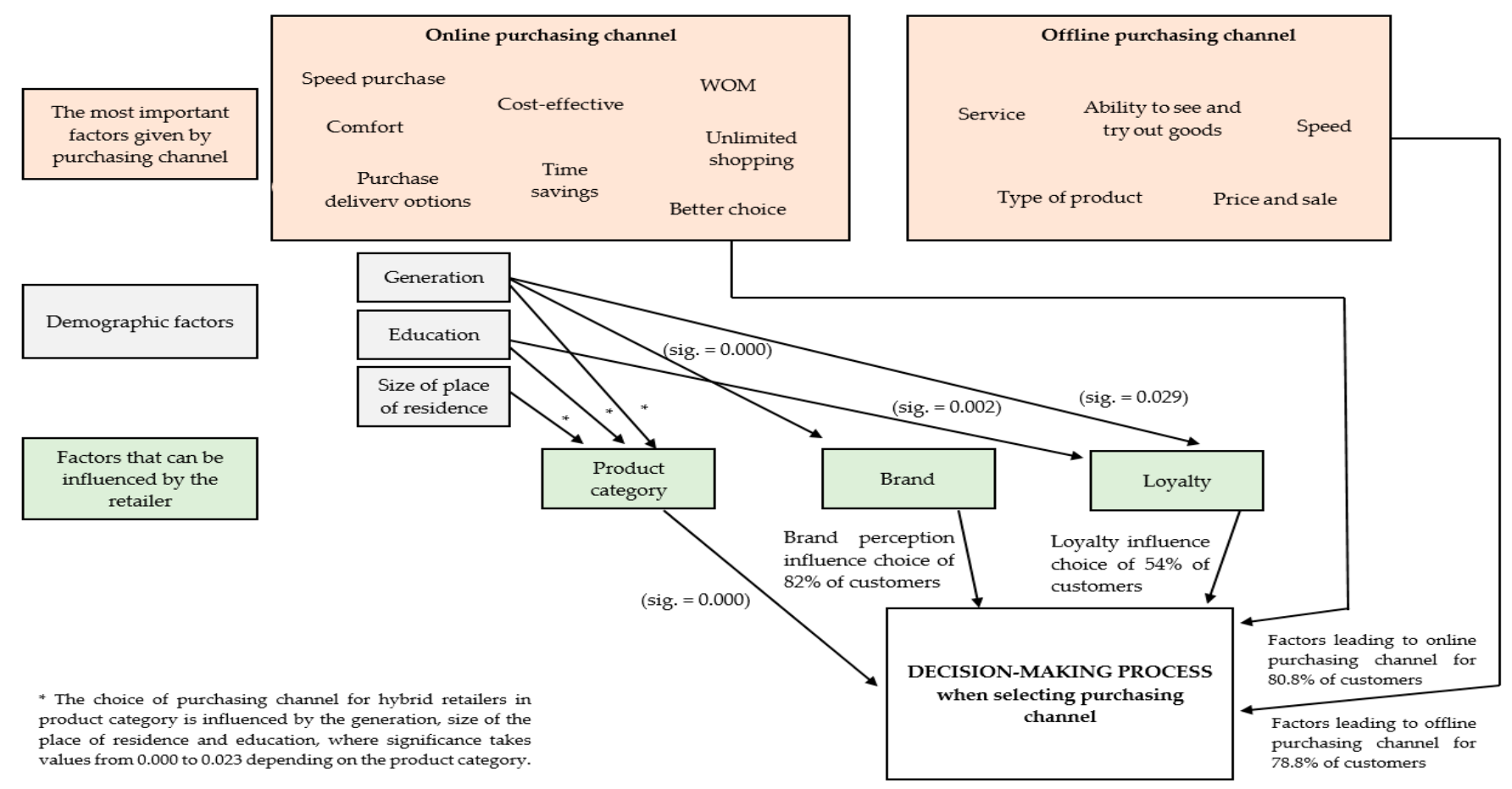

Figure 2. Factors influence the choice of purchasing channel.

As none of the examined demographic factors showed a significant influence on the decisive factors given by the purchasing channel in the case of the online shopping channel, it can be concluded that these factors revealed by the content analysis are decisive regardless of customers' characteristics. Thus, these factors are decisive in choosing this purchasing channel for all customers equally.

Based on the results of second content analysis, 18 factors that influence customers to shop offline were detected. The first five factors have the biggest impact: the ability to see and try out the goods, type of products, speed, price and sale, and service. The outputs showed that, for the customers, it is still important to have a chance to see, smell, touch, or try out the goods. The respondents chose this option in more than $50 \%$ of cases.

When analyzing these results, it should be noted that the distribution of the probability of the factors is significantly different for the factors within the online and offline purchasing channel. While the factors within the online purchasing channel are relatively balanced in distribution, in the case of the offline channel, the factor ability to see and try out goods prevails. This factor is the most decisive factor that influences the decision-making process for every second customer.

The results of the research are beneficial for the scientific field, as they show that, even after 25 years of online shopping in Czechia [46], customers are still attracted to the same factors in offline shopping. These factors, which we can call the benefits of offline shopping, have not yet been surpassed by the online environment. In future research, the question is whether the current online shopping boom associated with the COVID-19 pandemic will have a long-term effect on purchasing channel selection, whether the ratio between preferred purchasing channels will change, or whether this situational factor (COVID-19) will conform to the situational factor theory, which states that, once the trigger is gone, customer behavior returns to the state before it occurred [54]. 
For the practical sphere, the results are important because they clearly show factors that can be influenced by the retailer and that have a significant impact on the final choice of purchasing channel. These findings are most useful for hybrid retailers who need to adapt their processes not only offline but also online. To our best knowledge, it is possible to suggest to hybrid retailers to highlight the most important factors given by purchasing channel in marketing communication, depending on the changing logistics possibilities. In this way, they can influence customers in choosing a purchasing channel according to their available capacities (e.g., capacity fluctuations due to situational factors such as COVID-19). It was found that a product category influences the choice of purchasing channel, so hybrid retailers can tailor the offer within their channels and offer them the product categories that are most suitable for that channel. Hypermarkets are thus offered the opportunity to support the online channel by offering electronics or sportswear. Hybrid companies need to increase their customer loyalty, as a strategic decision to switch to the offline channel only found that half of customers would be loyal to the brand and would continue to shop with it, even though only offline purchases would be possible. Increasing loyalty would bring less customer loss to hybrid companies if they needed to go offline. However, the results of this study are also suitable for companies that still plan to move to a hybrid business model, as it was found that brand perception has a very high effect on the perception of trust in the online shopping channel.

One of the limitations of this study is the fact that the results are focused on a questionnaire survey and the primary data do not reflect the actual decision-making process when choosing a purchasing channel but only convey this process through specific questions. Respondents to these questions present how they would probably behave in the assumptions in the given situations, but there may be differences from the situation when the respondents would be really in the given situation. However, we assume that these differences will not be large in the examined area, given the situation that the purchase of products is a very frequent and well-known activity of the respondents.

\section{Conclusions}

The main purpose of the study was to investigate the factors that influence customers when they choose the purchasing channel. If retailers want to have a successful business, they should follow trends appearing on the consumer market. As the results from the research have shown, customers tend to purchase more and more online, but also traditional shopping is not dying as some may think. If the retailers use technological innovations and make the purchasing process more interesting, the customers would still like to stay in the offline space. Thus, retailers should try to give or create some kind of experience for customers to make it in a way the customers will always want to come back.

The customers like to experience. The customers come to the store to touch and feel the products, they like the presence of the goods, that the goods are available immediately, and they do not need to wait some time for delivery or pay delivery fees. They indeed come to the store much better informed but also with a higher disposition to purchase. They like the service which is connected to offline shopping, such as getting advice from the seller or gathering more information. We cannot forget there are still many customers who like the store atmosphere and social contact.

In the case of online purchasing channel, the customers mainly like that shopping online is cost-effective and comfortable for them. They like saving time. The customers can better compare prices and offerings of many online stores. However, what is very important in the case of online shopping is the design of these purchasing channels. e-shops and websites need to be user friendly, and they have to help the customers to choose exactly what they want. Otherwise, the customers could be annoyed. which can lead to the customers leaving the e-shops or websites.

As it is quite obvious from the research, there are still many customers who prefer offline purchasing channel, but more and more customers prefer the online purchasing channel. The retailers just need to react to the demand in the right way. Recently, the trend 
is the offer of both purchasing channels by retailers, to satisfy the wishes of both customers who prefer online and those who prefer an offline shopping channel. Hybrid companies are therefore reaping the benefits of both purchasing channels, which has also recently emerged in connection with the COVID-19 pandemic as the right strategic step for good sustainable brand management in the short (response to the consequences of a pandemic) and long term (increasing customer satisfaction in the selection of possible purchasing channels leading to greater loyalty). Besides, the results of this study show that purely brick-and-mortar retailers or e-tailers do not have to worry about expanding their business into a new purchasing channel. For brick-and-mortar retailers, up to $82 \%$ of customers will have more confidence in the online purchasing channel in the case of a well-known retail brand. On the contrary, even if an e-tailer switched to a purely offline shopping channel, $54 \%$ of its customers would remain loyal and continue to shop. Hypothetically, the addition of another purchasing channel could not only increase the satisfaction of current customers, but also gain completely new segments. The transition to a hybrid company, therefore, seems to be the right step for both brick-and-mortar retailers and e-tailers, and brand perception and loyalty can greatly facilitate this transition, but it is certainly important to be consistent in brand management to talk about its sustainability.

Supplementary Materials: The following are available online at https://www.mdpi.com/2071-1 050/13/5/2453/s1, Survey S1: Questions in the online questionnaire used to collect primary data, Table S1: Other factors leading to online purchasing channel, Table S2: Other factors leading to offline purchasing channel.

Author Contributions: All authors made substantial contributions to the conception and design of the work, the analysis, and the consideration of the main conclusions. All authors agreed to be personally accountable for their own contributions and for ensuring that questions related to the accuracy or integrity of any part of the work, even ones in which the author was not personally involved, are appropriately investigated, resolved, and documented in the literature. The individual contributions to the sections of the manuscript are specified as follows: introduction, V.B.; literature review, V.B.; materials and methods, R.B.; results, R.B. and V.B.; discussion, R.B.; conclusion, V.B.; and original draft preparation and editing, R.B. and V.B. All authors have read and agreed to the published version of the manuscript.

Funding: This paper was supported by the Ministry of Education, Youth and Sports Czech Republic within the Institutional Support for Long-term Development of a Research Organization in 2021.

Institutional Review Board Statement: The study was conducted according to the guidelines of the Declaration of Helsinki.

Informed Consent Statement: Informed consent was obtained from all subjects involved in the study.

Data Availability Statement: The data presented in this study are available on request from the corresponding author. The data are not publicly available due to privacy or ethical restrictions.

Conflicts of Interest: The authors declare no conflict of interest. The funders had no role in the design of the study; in the collection, analyses, or interpretation of data; in the writing of the manuscript, or in the decision to publish the results.

\section{References}

1. Grubor, A.; Maric, D. Contemporary Consumer in the Global Environment. In Proceedings of the CBU International Conference Proceedings, Prague, Czech Republic, 25-27 March 2015; Volume 3, pp. $28-36$.

2. Sharifonnasabi, Z.; Bardhi, F.; Luedicke, M.K. How globalization a_ects consumers: Insights from 30 years of CCT globalization research. Mark. Theory 2019, 20, 273-298. [CrossRef]

3. Grewal, D.; Hulland, J.; Kopalle, P.K.; Karahanna, E. The future of technology and marketing: A multidisciplinary perspective. J. Acad. Mark. Sci. 2019, 48, 1-8. [CrossRef]

4. Baruk, A.I.; Grzesiak, M. Cooperation between Final Purchasers and Offerors in the Online and Offline Environments vs. the Benefits Derived by Active Purchasers. Sustainability 2020, 12, 10462. [CrossRef]

5. Gallino, S.; Moreno, A. Integration of Online and Offline Channels in Retail: The impact of sharing reliable inventory availability information. Man SC 2014, 60, 1434-1451. [CrossRef] 
6. Zhang, M.; Ren, C.; Wang, G.A.; He, Z. The impact of channel integration on consumer responses in omnichannel retailing: The mediating effect of consumer empowerment. Electron. Comm. Res. Appl. 2018, 28, 181-193. [CrossRef]

7. Frasquet, M.; Miquel, M.J. Do channel integration efforts pay off in terms of online and offline customer loyalty? Int. J. Retail Dis. Manag. 2017, 45, 859-873. [CrossRef]

8. Atulkar, S.; Kesari, B. Satisfaction, loyalty and repatronage intentions: Role of hedonic shopping values. J. Retail. Consum. Serv. 2017, 39, 23-34. [CrossRef]

9. Dick, A.S.; Basu, K. Customer loyalty: Toward an integrated conceptual framework. J. Acad. Mark. Sci. 1994, 22, 99-113. [CrossRef]

10. Zeithaml, V.A.; Berry, L.L.; Parasuraman, A. The behavioral consequences of service quality. J. Mark. 1996, 60, 31-46. [CrossRef]

11. Melis, K.; Campo, K.; Breugelmans, E.; Lamey, L. The Impact of the Multi-channel Retail Mix on Online Store Choice: Does Online Experience Matter? J. Retail. 2015, 91, 272-288. [CrossRef]

12. Gupta, A.; Su, B.; Walterc, Z. Risk profile and consumer shopping behavior in electronic and traditional channels. Decis. Support Syst. 2004, 38, 347-367. [CrossRef]

13. Gensler, S.; Neslin, S.A.; Verhoef, P.C. The Showrooming Phenomenon: It's more than Just About Price. J. Interact. Mark. 2017, 38, 29-43. [CrossRef]

14. Schröder, H.; Zaharia, S. Linking multi-channel customer behavior with shopping motives: An empirical investigation of a German retailer. J. Retail. Consum. Serv. 2008, 15, 452-468. [CrossRef]

15. Ma, J. Does greater online assortment pay? An empirical study using matched online and catalog shoppers. J. Retail 2016, 92, 373-382. [CrossRef]

16. Cheema, A.; Papatla, P. Relative importance of online versus offline information for Internet purchases: Product category and Internet experience effects. J. Bus. Res. 2010, 63, 979-985. [CrossRef]

17. Li, C.Y. Why do online consumers experience information overload? An extension of communication theory. J. Inf. Sci. 2017, 43, 835-851. [CrossRef]

18. Chen, J.; Wang, H.; Gao, W. How do goal and product knowledge specificity influence online channel choice? A polynomial regression analysis. Elec. Comm. Res. Appl. 2019, 35, 100846. [CrossRef]

19. Marmol, M.; Fernandez, V. Trigger factors in brick and click shopping. Intang. Cap. 2019, 15, 57-71. [CrossRef]

20. Li, Z.E.; Lu, Q.; Talebian, M. Online versus bricks-and-mortar retailing: A comparison of price, assortment and delivery time. Inter. J. Prod. Res. 2014, 53, 1-14. [CrossRef]

21. Lazaris, C.; Vrechopoulos, A.; Doukidis, G.; Fraidaki, K. The Interplay of Omniretailing \& Store Atmosphere on Consumers Purchase Intention towards the Physical Retail Store. In Proceedings of the 12th European, Mediterranean \& Middle Eastern Conference on Information Systems (EMCIS), Athens, Greece, 1-2 June 2015.

22. Ansari, A.; Mela, C.F.; Neslin, S.A. Customer channel migration. J. Mark. Restaur. 2008, 45, 60-76. [CrossRef]

23. Sangkyu, P.; Dongwon, L. An empirical study on consumer online shopping channel choice behavior in omni-channel environment. Tele. Inf. 2017, 34, 1398-1407.

24. Kwon, W.-S.; Lennon, S.J. What induces online loyalty? Online versus offline brand images. J. Bus. Res. 2008, 62, 557-564. [CrossRef]

25. Bock, G.W.; Lee, J.; Kuan, H.H.; Kim, J.H. The Progression of Online Trust in the Multi-channel Retailer Context and the Role of Product Uncertainty. Dec. Supp. Syst. 2012, 53, 97-107. [CrossRef]

26. Hongyoun, H.K.; Kim, J. The Effect of Offline Brand Trust and Perceived Internet Confidence on Online Shopping Intention in the Integrated Multi-channel Context. Int. J. Retail Dis. Manag. 2009, 37, 126-141. [CrossRef]

27. Jones, C.; Kim, S. Influences of Retail Brand Trust, Off-line Patronage, Clothing Involvement and Website Quality on Online Apparel Shopping Intention. Int. J. Con. Stud. 2010, 34, 627-637. [CrossRef]

28. Frasquet, M.; Ruiz-Molina, M.-E.; Molla-Descals, A. The role of the brand in driving online loyalty for multichannel retailers. Int. Rev. Retail Dis. Con. Res. 2015, 25, 490-502. [CrossRef]

29. Hall, A.; Towers, N.; Shaw, D.R. Understanding how millennial shoppers decide what to buy: Digitally connected unseen journeys. Int. J. Retail Dis. Manag. 2017, 45, 498-517. [CrossRef]

30. Parment, A. Generation Y vs. Baby Boomers: Shopping behavior, buyer involvement and implications for retailing. J. Retail. Consum. Serv. 2013, 20, 189-199. [CrossRef]

31. Ladhari, R.; Gonthier, J.; Lajante, M. Generation Y and online fashion shopping: Orientations and profiles. J. Retail. Consum. Serv. 2019, 48, 113-121. [CrossRef]

32. Sullivan, P.; Hyun, S.-Y.J. Clothing Retail Channel Use and Digital Behavior: Generation and Gender Differences. J. Bus. Theory Pract. 2016, 4, 125-138. [CrossRef]

33. Taylor, P.; Gao, G. Generation X: America's Neglected "Middle Child" Factank. Pew Research Center. Available online: http:/ / www.pewresearch.org/fact-tank/2014/06/05/generation-X-a (accessed on 20 December 2020).

34. Herhausen, D.; Binder, J.; Schögel, M.; Herrmann, A. Integrating bricks with clicks: Retailer-level and channel-level outcomes of online-Offline channel integration. J. Retail. 2015, 91, 309-325. [CrossRef]

35. Cunningham, N. Consumer Perceptions of Shopping Channel Attributes and Risk Factors Influencing Apparel Purchases. Ph.D Thesis, University of Johannesburg, Johannesburg, South Africa, 2015. 
36. Birgelen, M.; Jong, A.; Ruyter, K. Multi-Channel Service Retailing: The Effects of Channel Performance Satisfaction on Behavioral Intentions. J. Retail 2006, 82, 367-377. [CrossRef]

37. Jones, M.A.; Mothersbaugh, D.L.; Beatty, S.E. Switching Barriers and Repurchase Intentions in Services. J. Retail. 2000, 76, $259-274$. [CrossRef]

38. Zhang, K.Z.K.; Christy, M.K.C.; Lee, M.K.O. OnlineService Switching Behavior: The Case of Blog Service Providers. J. Elec. Commer. Res. 2012, 13, 184-197.

39. Hult, G.T.M.; Sharma, P.N.; Morgeson, F.V.; Zhangd, Y. Antecedents and Consequences of Customer Satisfaction: Do They DifferAcross Online and Offline Purchases? J. Retail. 2019, 95, 10-23. [CrossRef]

40. Kushwaha, T.; Shankar, V. Single Channel vs. Multichannel Customers: Determinants and Value to Retailer S; Working Paper; Texas A\&M University: Laredo, DX, USA, 2008.

41. Chocarro, R.; Cortiñas, M.; Villanueva, M.L. Situational Variables in Online versus Offline Channel Choice. Elec. Commer. Res. Appl. 2013, 12, 347-361. [CrossRef]

42. Lynch, P.D.; Kent, R.J.; Srinivasan, S.S. The Global Internet Shopper: Evidence from Shopping Tasks in Twelve Countries. J. Advert. Res. 2001, 41, 15-23. [CrossRef]

43. Sarkar, R.; Das, S. Online Shopping vs Offline Shopping: A Comparative Study. Int. J. Sci. Res. Sci. Technol. $2017,3,424-431$.

44. Levin, A.M.; Levin, I.P.; Hath, C.E. Product Category Dependent Consumer Preferencesfor Online and Offline Shopping Features and their Influence on Multi-Channel Retail Alliances. J. Elec. Commer. Res. 2003, 4, 85-93.

45. Heinemann, G.; Schwarzl, C. New Online Retailing Innovation and Transformation; Springer: Berlin/Heidelberg, Germany, 2010; ISBN 978-3-8349-6378-9.

46. Thomas, J.S.; Sullivan, U.Y. Managing marketing communications with multichannel customers. J. Mark. 2005, 69, 239-251. [CrossRef]

47. A Small Historical Excursion Behind the First e-Shops. Available online: https://www.shopsys.cz/maly-historicky-exkurz-zaprvnimi-e-shopy/ (accessed on 20 December 2020).

48. Basher, A.; Ahmad, I.; Wasi, M. A study of influence of demographic factors on consumer impulse buying behavior. Int. J. Manag. Strategy 2012, 3, 1-18.

49. Uygun, M.; Ozciftci, V.; Divanoglu, S.U. Factors affecting online shopping behaviour of consumers. Organzasyon Yonet. Bilimleri. Derg. 2011, 3, 373-385.

50. Chakraborty, T.; Balakrishnan, J. Exploratory tendencies in consumer behaviour in online buying across gen $\mathrm{X}$, gen $\mathrm{Y}$ and baby boomers. Int. J. Value Chain Manag. 2017, 8, 135-150. [CrossRef]

51. Herrero, C.A.; Bosque, I.R. The Influence of the Commercial Features of the Internet on the Adoption of E-commerce by Consumers. Elec. Commer. Res. Appl. 2010, 9, 562-575. [CrossRef]

52. Venkatesan, R.; Kumar, V.; Ravishanker, N. Multichannel Shopping: Causes and Consequences. J. Mark. 2007, 71, 114-132. [CrossRef]

53. Tahal, R. Basic Methods of Primary Data Collection in Marketing Research (in Original Language: "Základní Metody Sběru Primárních Dat v Marketingovém Výzkumu"); C.H.Beck: Prague, Czech Republic, 2015; ISBN 978-80-7400-585-5.

54. Hand, C.; Riley, F.D.; Harris, P.; Singh, J.; Rettie, R. Online grocery shopping: The influence of situational factors. Eur. J. Mark 2009, 43, 1205-1219. [CrossRef] 